\title{
EVALUASI KECERNAAN PAKAN, KANDUNGAN GOSSYPOL DAN ASAM SIKLOPROPENOAT DALAM ORGAN, DAN PERTUMBUHAN IKAN MAS YANG DIBERI FORMULASI PAKAN DENGAN KANDUNGAN TEPUNG BIJI KAPUK BERBEDA
}

\author{
O.D. Subakti Hasan*), Enang Harris*), M. Agus Suprayudi*), \\ Dedi Jusadi*), dan Eddy Supriyono*) \\ *) Jurusan Penyuluhan Perikanan Sekolah Tinggi Perikanan \\ Jl. Cikaret No. 2, Kotak Pos 155, Bogor 16001 \\ E-mail: otiesh3009@yahoo.com \\ ${ }^{*}$ Departemen Budidaya Perairan-Fakultas Perikanan dan IImu Kelautan, \\ Institut Pertanian Bogor \\ Jl. Lingkar Akademik, Kampus IPB Darmaga, Bogor 16680
}

(Naskah diterima: 20 Juni 2012; Disetujui publikasi: 9 April 2013)

\begin{abstract}
ABSTRAK
Biji kapuk memiliki potensi sebagai bahan baku lokal pakan ikan karena ketersediaannya dan mengandung protein dan asam lemak linoleat yang cukup tinggi, namun juga mengandung zat antinutrisi gossypol dan asam siklopropenoat. Oleh karena itu, penelitian ini bertujuan untuk mengevaluasi pemanfaatan tepung biji kapuk ini dalam pakan terhadap kecernaan pakan, gambaran darah, dan kinerja pertumbuhan ikan mas. Hewan uji yang digunakan adalah ikan mas berukuran $5 \mathrm{~g}$, yang dipelihara dalam akuarium kaca berukuran $80 \mathrm{~cm} \times 50 \mathrm{~cm} \times 40 \mathrm{~cm}$ dengan kepadatan 20 ekor/akuarium. Perlakuan yang dicobakan adalah pakan uji yang mengandung tepung biji kapuk berbeda yaitu $0 \%, 10 \%, 20 \%, 30 \%, 40 \%$, dan $50 \%$ bahan kering. Ikan diberi pakan uji secara satiasi tiga kali sehari selama 60 hari. Hasil penelitian menunjukkan perbedaan kadar tepung biji kapuk dalam pakan memberikan pengaruh berbeda nyata $(P<0,05)$ terhadap pertumbuhan ikan dan pemanfaatan pakan. Laju pertumbuhan harian, efisiensi pakan, retensi protein, dan lemak menurun dengan meningkatnya kandungan tepung biji kapuk dalam pakan. Aktivitas enzim pencernaan dan koefisien kecernaan pakan juga menurun dengan meningkatnya kandungan tepung biji kapuk dalam pakan. Peningkatan tepung biji kapuk dalam pakan meningkatkan kandungan gossypol dalam darah, hati, dan ginjal ikan mas, dan selanjutnya menurunkan kecernaan dan pemanfaatan nutrien pakan bagi pertumbuhan ikan mas. Berdasarkan hasil penelitian dapat disimpulkan bahwa kandungan biji kapuk 7 10\% memperlihatkan pertumbuhan terbaik.
\end{abstract}

KATA KUNCI: kecernaan, parameter darah, pertumbuhan, tepung biji kapuk

ABSTRACT: Evaluation of feed digestibility, content of gossypol and cyclopropenoate acid in organ and growth performance of common carp, Cyprinus carpio, fed by formulated diets containing different ratio of kapook seed meal. By: O.D. Subakti Hasan, Enang Harris, M. Agus Suprayudi, Dedi Jusadi, and Eddy Supriyono

This experiment was conducted to evaluate the use of kapook seed as protein source and the effect of gossypol and cyclopropenoate acid on digestibility and performances of common carp juveniles. A triplicated experiment was conducted using carp juvenile 
with an initial body weight of $5 \mathrm{~g}$, stocked in aquarium of $80 \mathrm{~cm} \times 50 \mathrm{~cm} \times 40 \mathrm{~cm}$ at density of 20 fish. The fish were cultured for 60 days and fed diet containing different ratio of kapook seed meal, i.e. 0\%, 10\%, 20\%, 30\%, 40\%, and 50\% dry matter. The fish were fed ad libitum in each feeding and fed 3 times a day. The results showed that the utilization of kapook seed meal in the diets had significant different $(P<0.05)$ on the growth performances and feed utilization. The daily growth rate, feed efficiency, protein and lipid retentions decreased with increased the inclusion levels of kapook seed meal in the test diets. Digestive enzyme activities and digestibility coefficient of the diets also decreased with increased the kopook seed meal content in the diets. The increased of kapook seed meal levels in the diet, increased the contents both of gossypol and cyclopropionate acid in fish blood, liver, and kidney, and furthermore reduced the digestibility and utilization of nutrient diet for common carp growth The results suggest that formulation diet for carp containing 7 10\% of kapook seed revealed good growth performance.

\section{KEYWORDS: digestibility, antinutrient, growth, common carp, kapook seed meal}

\section{PENDAHULUAN}

Pada budidaya ikan mas secara intensif, pemberian pakan buatan dapat mencapai hampir $100 \%$ karena pakan alami sudah tidak mampu menyuplai kebutuhan nutrisi untuk pertumbuhan ikan secara optimal. Protein dan lemak merupakan komponen nutrisi yang sangat penting dalam pakan ikan, karena berperan dalam sistem kerja enzim, hormon, pergantian sel jaringan, dan pertumbuhan, serta sebagai sumber energi pada ikan (Wilson, 2002). Saat ini, pakan ikan mas banyak berasal dari industri pakan ikan dengan bahan baku banyak mengandalkan tepung ikan sebagai sumber protein hewani, tepung kedelai sebagai sumber protein nabati, serta minyak ikan dan minyak kedelai sebagai sumber asam lemak esensial. Penggunaan bahan tersebut dalam pakan ikan ini karena keduanya memiliki profil asam amino dan asam lemak yang seimbang dengan yang dibutuhkan ikan serta mengandung sangat sedikit senyawa anti nutrisi (Allan et al., 2000). Namun ketersediaan tepung ikan dan tepung kedelai tersebut bersifat fluktuatif dan harganya semakin mahal, bahkan Indonesia tergolong pengimpor tepung ikan dan tepung kedelai. Oleh karena itu, perlu dicari sumber protein alternatif (lokal) yang memiliki potensi cukup besar dengan harga yang murah, khususnya dari hasil samping pertanian.

Biji kapuk merupakan hasil samping industri pertanian yang cukup banyak di Indonesia terutama di Jawa Tengah dan Jawa Timur dengan potensi sekitar 8.324 ton/tahun (Sangaji, 1998). Biji kapuk ini memiliki kan- dungan protein kasar antara 27\%-32\% dan minyak 22\%-44\% (Parakkasi, 1983; Hartutik, 2000; Mazida, 2007), dan asam lemak esensial linoleat ( $27 \%$ total lemak), dan belum dimanfaatkan dengan optimum. Berdasarkan hal tersebut, maka biji kapuk ini berpotensi sebagai sumber bahan baku lokal untuk pakan ikan (Yildirim et al., 2004). Namun selain mengandung protein cukup tinggi, biji kapuk juga mengandung zat antinutrisi gossypol (polyphenol) dan asam siklopropenoat (Hertrampf \& Felicita, 2000; Francis et al., 2001) yang berpotensi toksik pada ikan. Asam-asam phenolic yang terdapat dalam gossypol dapat membentuk senyawa komplek dengan protein serta menghambat kerja enzim proteolitik seperti tripsin dan pepsin (Morgan, 1989; Cai et al., 2004).

Beberapa pembudidaya di Blitang, Sumatera Selatan, telah memanfaatkan biji kapuk ini sebagai pakan utama pada pembesaran ikan bawal air tawar (Colossoma macropomum) di kolam dengan rasio konvesi pakan 2,5-3 (Suyanto, komunikasi pribadi, 2009), tanpa memberikan efek mal nutrisi dan toksik. Sementara Muskita (2012) melaporkan bahwa kandungan tepung biji kapuk dalam pakan udang vaname (Litopenaeus vannamei) tidak boleh melebihi 5\%. Penggunaan biji kapuk sebagai bahan baku pakan ikan informasinya masih sangat terbatas. Namun demikian, beberapa peneliti telah melaporkan tentang pemanfaatan tepung biji kapas yang merupakan bahan mirip biji kapuk dalam pakan beberapa jenis ikan. Tingkat kecernaan tepung biji kapas pada ikan lele berkisar $71,2 \%-90,6 \%$; dan pada ikan mas antara 46,5\%-87,3\% (Hertrampf 
\& Felicitas, 2000). Penggunaan tepung biji kapas sebanyak 10\% dan 30\% tidak menurunkan pertumbuhan berturut-turut pada ikan channel catfish dan Tilapia aurea (Robinson \& Brent, 1989). Selanjutnya Robinson \& Li (1994) melaporkan bahwa ikan channel catfish yang diberi pakan mengandung tepung biji kapas sebanyak 51,25\% dan lysin 0,65\% menghasilkan pertumbuhan dan komposisi kimia daging ikan yang tidak berbeda dengan ikan yang diberi pakan tepung bungkil kedelai sebanyak $42 \%$. Berdasarkan hal tersebut, maka penelitian ini dilakukan dengan tujuan menganalisis pemanfaatan biji kapuk sebagai sumber protein, efek gossypol, dan asam lemak siklopropenoat yang terkandung dalam pakan berbahan baku tepung biji kapuk terhadap kecernaan pakan, gambaran darah, serta kinerja pertumbuhan ikan mas.

\section{BAHAN DAN METODE}

Penelitian ini dilakukan di Hatcheri dan Laboratorium Nutrisi Ikan Jurusan Penyuluhan Perikanan Sekolah Tinggi Perikanan (STP) Bogor pada bulan Februari 2011-April 2012. Analisis kimia bahan pakan, pakan, gambaran darah, aktivitas enzim, dan kualitas air media dilakukan di Laboratorium Nutrisi Ikan, Laboratorium Kesehatan Ikan, dan Laboratorium Lingkungan pada Departemen Budidaya Perairan Fakultas Perikanan dan Ilmu Kelautan IPB, Laboratorium Ilmu dan Teknologi Pakan Departemen IImu Nutrisi dan Teknologi Fakultas Peternakan IPB, Laboratorium Biokimia PAU IPB, Seafast Centre PAU IPB, dan Pusat Penelitian Biologi LIPI Bogor.

\section{Pakan Uji}

Pakan uji yang dicobakan adalah pakan buatan dengan kandungan iso-protein dan iso-energi. Perlakuan yang diberikan adalah kandungan tepung biji kapuk (TBK) yang berbeda dalam pakan, yaitu K (0\% TBK), A (10\% TBK), B (20\% TBK), C (30\% TBK), D (40\% TBK), dan $\mathrm{E}$ (50\% TBK) dengan komposisi pakan seperti pada Tabel 1 .

\section{Hewan Uji}

Hewan uji yang digunakan adalah benih ikan mas yang diperoleh dari Instalasi Balai Penelitian dan Pengembangan Budidaya Air Tawar, Cijeruk-Bogor. Benih ikan mas sebanyak 500 ekor dipelihara selama satu minggu dalam tangki berukuran $1,5 \mathrm{~m}^{3}$ dan diberi pakan komersial untuk aklimatisasi.

\section{Pemeliharaan Hewan Uji}

Setelah satu minggu aklimatisasi, sebanyak 360 ekor ikan berbobot rata-rata $5 \mathrm{~g}$ per ekor ditebar ke dalam 18 akuarium (berukuran 80 $\mathrm{cm} \times 50 \mathrm{~cm} \times 40 \mathrm{~cm}$ yang terhubung dengan sistem resirkulasi) dengan kepadatan 20 ekor/ akuarium. Tiap akuarium diberi aerasi, dan dua buah heater (pemanas air) pada bak tandon. Sebelum ditimbang dan diberi pakan uji, ikan dipuasakan terlebih dahulu selama 24 jam dengan tujuan menghilangkan sisa pakan dalam saluran pencernaan selama masa aklimatisasi.

Ikan dipelihara selama 60 hari dan diberi pakan uji secara at satiation dengan frekuensi tiga kali sehari $(07.00,12.00$, dan 17.00). Untuk mempertahankan kualitas air, setiap hari dilakukan penyiponan dan pergantian air pada tandon sebanyak 30\%. Nilai kisaran parameter kualitas air selama penelitian adalah suhu $28^{\circ} \mathrm{C}$ $30^{\circ} \mathrm{C}$; pH 6,5-7,5; dan oksigen terlarut 7-8 mg/L.

\section{Pengambilan Sampel Darah dan Organ Ikan}

Pada awal dan akhir penelitian, sebanyak empat ekor ikan dari setiap perlakuan diambil secara acak, ditimbang. Ikan tersebut diambil darahnya untuk menghitung haemoglobin dan haematokrit dengan metode Humason (1985). Selain itu, darah ikan juga diambil untuk mengukur kandungan gossypol dan asam lemak sikloporpenoat. Selanjutnya keempat ekor ikan tersebut dibedah dan diambil organ hati dan ginjal untuk analisis kandungan gossypol dan asam lemak sikloporpenoat serta usus untuk analisis aktivitas enzim pencernaan (Muskita, 2012).

\section{Uji Kecernaan Pakan}

Ikan dipelihara selama 30 hari dan diberi pakan perlakuan yang sudah ditambahkan sebanyak $0,5 \% \mathrm{Cr}_{2} \mathrm{O}_{3}$ sebagai indikator kecernaan (Takeuchi, 1988) secara at satiation dengan frekuensi tiga kali sehari 00.70, 12.00, 17.00 WIB. Sebelum pengumpulan feses, ikan diadaptasikan dengan pakan uji yang mengandung krom tersebut selama satu minggu. Pada minggu ke-2 setelah pemberian pakan, sisa pakan dibersihkan dengan penyiponan, lalu dilakukan pengumpulan feses setiap tiga jam selama tiga minggu. Feses tersebut dikeringkan dalam oven bersuhu $110^{\circ} \mathrm{C}$ selama 4-6 jam untuk selanjutnya dianalisis kandungan nutrien, $\mathrm{Cr}_{2} \mathrm{O}_{3}$, dan energi. 
Tabel 1. Komposisi bahan dan proksimat pakan uji (\% bobot kering)

Table 1. Composition and proximate analysis of the test diets (\% dry matter)

\begin{tabular}{lcccccc}
\hline \multicolumn{1}{c}{$\quad \begin{array}{c}\text { Bahan pakan } \\
\text { Feed ingredients }\end{array}$} & \multicolumn{5}{c}{ Pakan uji (Test diet s) (\% TBK) } \\
\cline { 2 - 7 } & K (0) & A (10) & B (20) & C (30) & D (40) & E (50) \\
\hline Tepung ikan (Fish meal) & 15 & 15 & 15 & 15 & 15 & 15 \\
Tepung biji kapuk (Kapook seed meal) & 0 & 10 & 20 & 30 & 40 & 50 \\
Tepung bungkil ke delai (Soybean meal) & 23 & 20 & 19.6 & 13.6 & 10.6 & 5.6 \\
DDGS 1) & 24 & 20 & 17 & 15 & 15 & 15 \\
Tepung pollard (Pollard meal) & 29.9 & 26.9 & 20.3 & 18.3 & 11.3 & 6.3 \\
Tepung sagu (Sago meal) & 2 & 2 & 2 & 2 & 2 & 2 \\
Minyak sawit (Palm oil) & 1 & 1 & 1 & 1 & 1 & 1 \\
Minyak ikan (Fish oil) & 2 & 2 & 2 & 2 & 2 & 2 \\
Premix 2) & 3.1 & 3.1 & 3.1 & 3.1 & 3.1 & 3.1 \\
\hline
\end{tabular}

\section{Komposisi proksimat (\% bahan kering)}

Proximate analysis (\% dry matter)

$\begin{array}{lcccccc}\text { Protein kasar (Crude protein) } & 36 & 36.1 & 36.2 & 35.3 & 35.4 & 36.4 \\ \text { Lemak (Lipid) } & 11.4 & 12.3 & 11.4 & 12.2 & 12.1 & 11.6 \\ \text { Abu (Ash) } & 8.1 & 8.2 & 8.2 & 8.5 & 8.6 & 8.7 \\ \text { Serat kasar (Crude fibre) } & 0.1 & 0.1 & 0.1 & 0.1 & 0.2 & 0.3 \\ \text { BETN (NFE) }{ }^{3)} & 43.7 & 42.9 & 43.6 & 43.2 & 43.1 & 43.4 \\ \text { FG (Free gossypol) (mg/L) } & 0.0 & 16.8 & 26.1 & 49.1 & 59.1 & 75.1 \\ \text { CPA (mg/L) (4) } & 0.0 & 0.2 & 0.3 & 0.4 & 0.5 & 0.6 \\ \text { Energi total (kkal/kg) 5) } & 4,509 & 4,537 & 4,558 & 4,486 & 4,571 & 4,379 \\ \text { Gross energy (kcal/kg) 5) } & & & & & & \\ \text { Energi/protein (kkal/g protein) } & 13.5 & 13.6 & 13.6 & 13.8 & 13.9 & 13.0 \\ \text { Energy/protein (kcal/g protein) } & & & & & & \end{array}$

1) Dried Destillers Grains with Solubles

2) Komposisi vitamin dan mineral mix (dalam $1 \mathrm{~kg}$ premix) / Vitamin and mineral premix composition (in 1 kg of premix): Vit. A 4.000.000 IU; Vit. D3 800.000 IU; Vit. E 4.500 IU; Vit. K3 450 mg; Vit. B1 450 mg; Vit. B1 350 mg; Vit. B6 480 mg; Vit. B1 26 mg; Ca-d panthothenad 2.400 mg; Folic Acid 270 mg; Nochotinc Acid 7.200 mg; Choline Chloride 28.000 mg; Feros 8.500 mg; Copper 700 mg; Manganese 18.500 mg; Zinc 14.000 mg; cobalt 50 mg; lodine 70 mg; Selenium 35 mg; Choline Chlroride 0,5 g; Lysin+metionin (1:1) $0,19 \mathrm{~g}$

3) BETN (Bahan Ekstrak tanpa Nitrogen) / NFE (Nitrogen Free Extract)

4) CPA (Asam siklopropenoat / cyclopropenoate acid)

5) Energi total dihitung berdasarkan nilai ekuivalen untuk karbohidrat 4,1 kcal/g, lemak 9,5 kcal/g, dan protein $5,6 \mathrm{kcal} / \mathrm{g}$ (Calculation from the determined protein, lipid and NFE of the diet using gross energy convertion coefficients of $4.1 ; 9.5$, and $5.6 \mathrm{kcal} / \mathrm{kg}$ respectively) (National Research Council, 1993)

\section{Parameter yang Dievaluasi}

Beberapa parameter pertumbuhan ikan dan pemanfaatan pakan uji yang dievaluasi dalam penelitian ini yaitu:

a. Kecernaan pakan

Koefisien kecernaan pakan (KP) yang me- liputi: bahan kering (BK), protein kasar (P), lemak (L), karbohidrat (BETN), dan energi (E) dihitung berdasarkan rumus berikut (Abimorad \& Carneiro, 2007):

$$
\mathrm{KP}(\%)=\left[1-\left[\frac{\mathrm{Mp} \times \mathrm{Nf}}{\mathrm{Mf} \times \mathrm{Np}}\right]\right] \times 100
$$


di mana:

$\mathrm{Mp}=$ Kandungan indikator $\mathrm{Cr}_{2} \mathrm{O}_{3}$ (bobot kering) dalam pakan

$\mathrm{Mf}=$ Kandungan indikator $\mathrm{Cr}_{2} \mathrm{O}_{3}$ (bobot kering) dalam feses

$\mathrm{Np}=$ Kandungan nutrien (bobot kering) dalam pakan

$\mathrm{Nf}=$ Kandungan nutrien (bobot kering) dalam feses

b. Konsumsi pakan (Bores et al., 2006)

Konsumsi pakan dihitung dengan menimbang total pakan yang akan diberikan dikurangi jumlah sisa pakan

c. Sintasan (Zonneveld et al., 1991)

Sintasan (\%) = \{Jumlah ikan akhir (ekor)/ Jumlah ikan awal (ekor) $\} \times 100$

d. Laju pertumbuhan harian (Huisman, 1976)

$$
\text { Wt }=W_{0}(1+0.001 \alpha)^{t}
$$

di mana:

Wt = Rata-rata bobot ikan akhir (g)

Wo = Rata-rata bobot ikan awal (g)

$\mathrm{t}=$ Lama pemeliharan (hari)

$\alpha=$ Laju pertumbuhan harian (\%/hari)

e. Efisiensi pakan (Bores et al., 2006)

Efisiensi pakan = Pertambahan bobot biomassa (bobot basah) / Bobot konsumsi pakan (bobot kering)

f. Retensi protein dan retensi lemak (Takeuchi, 1988)

Retensi protein, lemak $(\%)=100 \times$ PPertambahan protein, lemak tubuh (g) / Jumlah konsumsi protein, lemak $(\mathrm{g})\}$

\section{Analisis Kimia dan Statistik}

Analisis proksimat terhadap bahan baku, pakan, biji kapuk, dan tubuh ikan yang meliputi: kadar air, protein kasar, lemak, serat kasar, dan abu dilakukan berdasarkan metode AOAC (1995). Analisis kadar kromium sampel pakan dan feses didasarkan atas prosedur Takeuchi (1988). Analisis kandungan gossypol dalam darah, hati dan ginjal diukur menggunakan High Performance Liquid Chromatography (HPLC), sementara kandungan asam siklopropenoat dalam jaringan tersebut diukur menggunakan gas kromatografi (Zahirma, 1986). Analisis akitivitas enzim pencernaan meliputi amilase dan protease (Bergmeyer \& Grassi, 1983) serta lipase (Borlongan, 1990).
Data tingkat kecernaan pakan, aktivitas enzim pencernaan, jumlah konsumsi pakan, kandungan gossypol dan asam lemak siklopropenoat dalam jaringan (hati, ginjal, dan darah), laju pertumbuhan harian, tingkat sintasan, efisiensi pakan, retensi protein, dan retensi lemak masing-masing dianalisis sidik ragam. Jika ada perbedaan nyata, maka dilanjutkan uji BNT pada selang kepercayaan 95\% menggunakan program SPSS 11 .

\section{HASIL DAN BAHASAN}

Hasil pengamatan tingkat kecernaan pakan uji disajikan pada Gambar 1A. Pada Gambar tersebut menunjukkan bahwa tingkat kecernaan bahan kering dan nutrien pakan menurun dengan meningkatnya kandungan tepung biji kapuk dalam pakan. Meskipun tingkat kecernaan protein dan lemak tidak berbeda nyata $(P<0,05)$ antara pakan yang mengandung $0 \%$, 10\%, dan 20\% tepung biji kapuk, namun secara kumulatif telah menurunkan kecernaan energi pakan, sehingga ikan yang diberi pakan mengandung tepung biji kapuk tersebut sudah mengalami penurunan ketersediaan energi tercerna. Hal ini akan berdampak pada pemanfaatan protein yang lebih banyak untuk sumber energi bagi ikan, dan akan menurunkan pertumbuhan dan retensi protein. Rendahnya tingkat kecernaan pakan antara lain disebabkan oleh menurunnya aktivitas enzim amilase, dan protease (Gambar 1B) dengan meningkatnya kandungan tepung biji kapuk dalam pakan. Tepung biji kapuk mengandung zat anti nutrisi, gossypol yang dapat membentuk senyawa kompleks dengan protein dan menghambat kerja enzim proteolitik seperti tripsin dan pepsin (Cai et al., 2004).

Tingkat konsumsi pakan selama 60 hari pemeliharaan menunjukkan adanya perbedaan yang nyata $(P<0,05)$ di antara perlakuan (Gambar 2). Semakin tinggi penggunaan tepung biji kapuk dalam pakan, konsumsi pakan oleh ikan uji semakin menurun. Hal ini menunjukkan bahwa tepung biji kapuk mempengaruhi palatabilitas pakan pada ikan mas. Palatabilitas yang rendah tersebut diduga akibat rasa dan aroma pakan tidak seperti pakan tanpa tepung biji kapuk yang beraroma tepung ikan, sehingga pakan yang dimakan sedikit. Menurut Ayuningsih (1994), bungkil biji kapuk merupakan bahan pakan yang kurang disukai oleh ternak ruminansia, namun demikian konsumsinya tidak berbeda nyata jika dibandingkan dengan bungkil kedelai atau bungkil kelapa. 

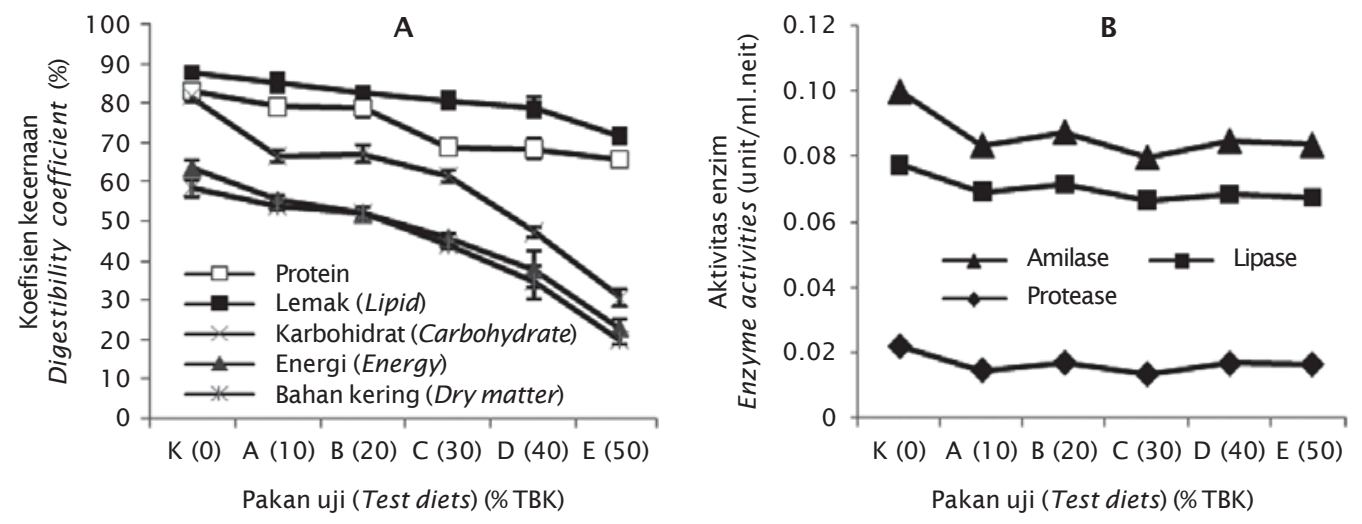

Gambar 1. Tingkat kecernaan pakan uji (A) dan aktivitas enzim pencernaan dalam usus ikan uji (B)

Figure 1. Apparent digestibility coefficient of test diets $(A)$ and enzyme activities in digestive track of fish test (B)

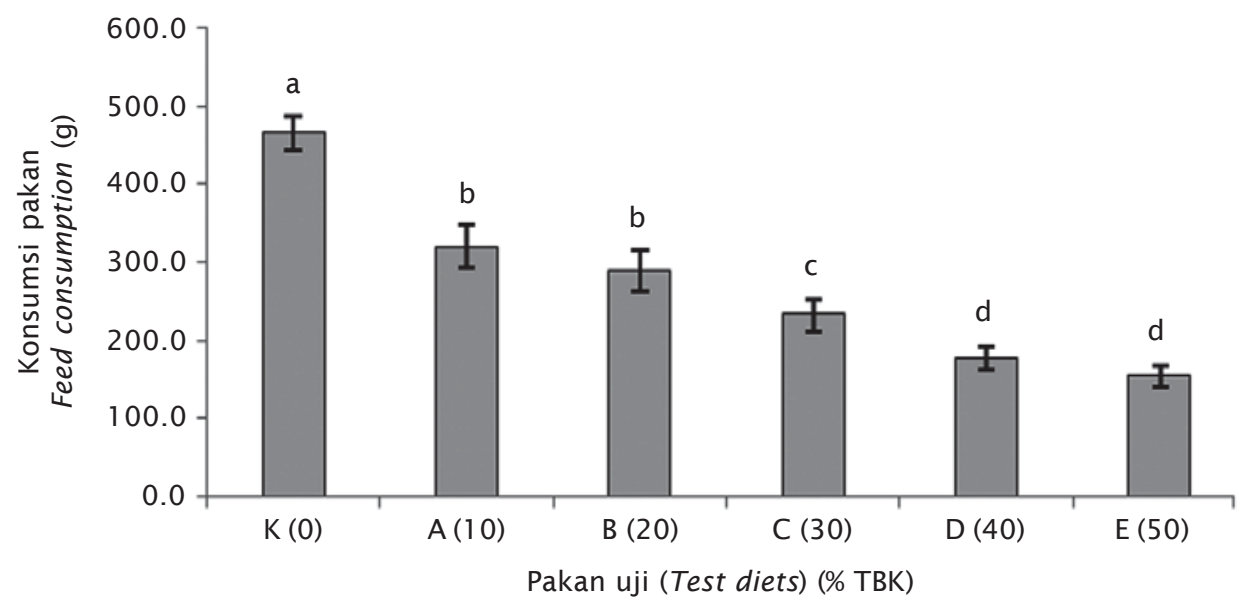

Gambar 2. Total konsumsi pakan uji oleh ikan uji selama 60 hari pemeliharaan

Figure 2. Total feed consumption of fish test for 60 days rearing period

Hal ini kemungkinan disebabkan karena bungkil biji kapuk tidak bisa berperan sebagai perangsang bau yang baik karena baunya tidak tajam. Selain itu, rasanya yang hampir tidak terasa, di samping bentuk fisiknya agak keras dibandingkan dedak, bungkil kelapa dan bungkil kedelai. Oleh karena itu, untuk pemberiannya pada ikan sebaiknya dalam formulasi pakan ikan dikombinasikan dengan bahan lain yang lebih merangsang bau dan rasanya. Penggunaan tepung biji kapuk sebanyak $10 \%$ dalam pakan sudah menurunkan secara nyata tingkat konsumsi pakan uji pada ikan mas.

Salah satu faktor penyebab tidak mampunya ikan mas memanfaatkan tepung biji kapuk untuk pertumbuhannya adalah adanya kandungan gossypol dalam tepung biji kapuk. Hasil analisis kandungan gossypol dalam pakan uji tersebut berkisar antara 16,8-75,2 $\mathrm{mg} / \mathrm{L}$ dan meningkat dengan meningkatnya penggunaan tepung biji kapuk tersebut dalam pakan. Hasil analisis pada darah, hati, dan ginjal ikan menunjukkan adanya peningkatan kandungan gossypol dengan meningkatnya penggunaan tepung biji kapuk dalam pakan (Gambar 3). Hasil penelitian ini menunjukkan bahwa pada kandungan gossypol sebanyak $0,70 \mathrm{mg} / \mathrm{L}$ dalam hati, $0,25 \mathrm{mg} / \mathrm{L}$ dalam ginjal, dan 1,42 mg/L dalam darah secara nyata telah menurunkan laju pertumbuhan dan pemanfaatan pakan pada 


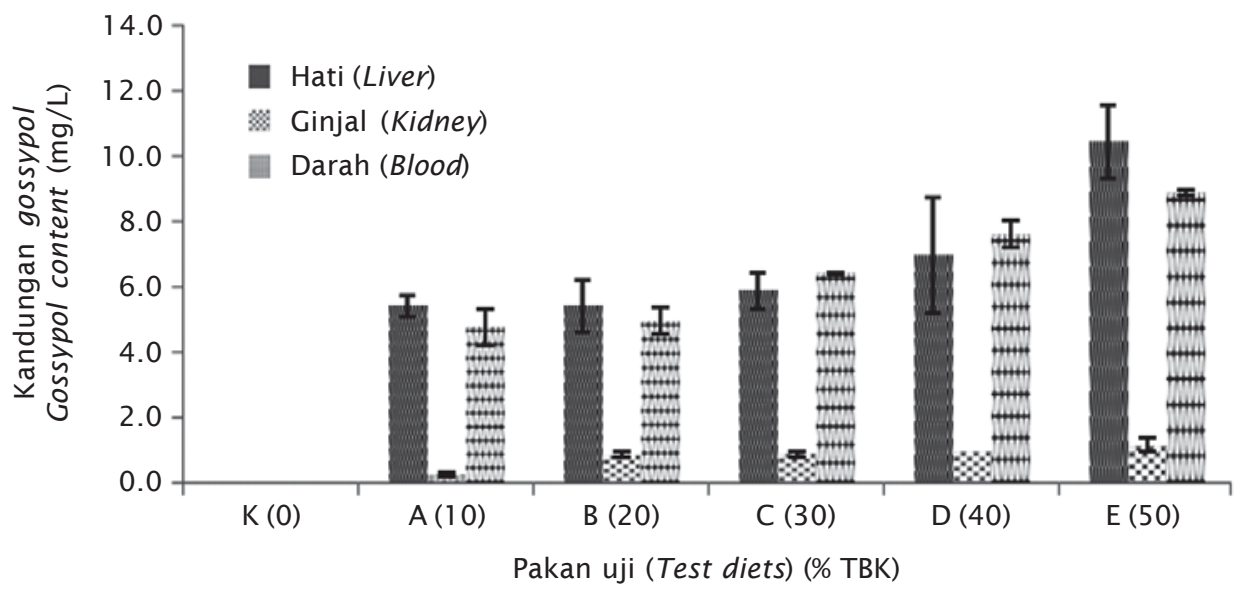

Gambar 3. Kandungan gossypol dalam jaringan tubuh ikan uji setelah pemberian pakan uji

Figure 3. Gossypol content in some tissue of fish test after feeding

ikan mas. Sementara Mbahinzireki et al. (2001) melaporkan bahwa kandungan gossypolyang sudah berefek toksik pada ikan tilapia, Oreochromis spp. yaitu $700 \mathrm{mg} / \mathrm{L}$ dan ikan telah mengalami penurunan pertumbuhan dan efisiensi pakan. Perbedaan kadar gossypol yang menyebabkan toksik pada ikan disebabkan oleh spesies, umur dan ukuran ikan, komposisi pakan, dan kondisi lingkungan ( $\mathrm{Li} \&$ Robinson, 2006). Selanjutnya dikatakan bahwa metode analisis gossypol juga berpengaruh terhadap perbedaan laporan nilai kandungan atau toksisitas gossypol. Menurut Chamkasem (1988), pengukuran dengan metode calorimetrik akan menghasilkan nilai kandungan gossypol yang lebih tinggi daripada metode HPLC.

Selain gossypol, tepung biji kapuk juga mengandung asam lemak siklopropenoat yang dikenal memiliki sifat toksik pada hewan darat. Asam lemak siklopropenoat ini pada umumnya menyebabkan berbagai efek negatif yang merugikan baik secara ekonomis maupun produksi, terutama bila semakin meningkat dosis pemberian bahan pakan yang mengandung asam siklopropenoat (Phelps et al., 1964). Asam lemak siklopropenoat juga menyebabkan meningkatnya kandungan asam stearat dan menurunnya asam oleat pada beberapa jaringan seperti pada plasma darah, hati, ovari dan jantung hewan darat (Mairizal, 1998). Pakan uji yang digunakan dalam penelitian ini juga mengandung asam siklopropenoat berkisar antara 0,21 1-0,596 mg/L dan meningkat dengan meningkatnya jumlah tepung biji kapuk dalam pakan. Hasil analisis pada darah, hati dan ginjal menunjukkan adanya peningkatan kandungan asam siklopropenoat dengan meningkatnya penggunaan tepung biji kapuk dalam pakan (Gambar 4).

Ketidakmampuan ikan mas memanfaatkan tepung biji kapuk dalam pakan meskipun dengan dosis rendah (10\%), kemungkinan disebabkan adanya pengaruh simultan antara gossypol dan asam siklopropenoat dari tepung biji kapuk tersebut yang menyebabkan tingginya efek negatif dalam hal pemanfaatan pakan bagi pertumbuhan ikan. Sementara tepung biji kapas (bahan yang mirip tepung biji kapuk) yang juga mengandung gossypol, namun hampir tidak memiliki asam siklopropenoat masih mampu dimanfaatkan sampai kadar tertentu bagi pertumbuhan beberapa jenis ikan budidaya. Substitusi tepung kedelai dengan TBK pada pakan yuwana udang vaname, dapat diberikan sampai batas $5 \%$ (Muskita, 2012). Luo et al. (2006) melaporkan bahwa ekstrak tepung biji kapas dapat digunakan sebanyak $30 \%$ dalam pakan yuwana ikan rainbow trout untuk menggantikan sebagian penggunaan protein dari tepung ikan. Robinson \& Li (1994) juga melaporkan bahwa penggunaan tepung biji kapas sebanyak $51,3 \%$ yang ditambahkan 0,65\% lisin dalam pakan memberikan laju pertumbuhan dan komposisi kimia tubuh ikan channel catfish yang relatif sama jika diberi pakan mengandung $42 \%$ tepung bungkil kedelai. 


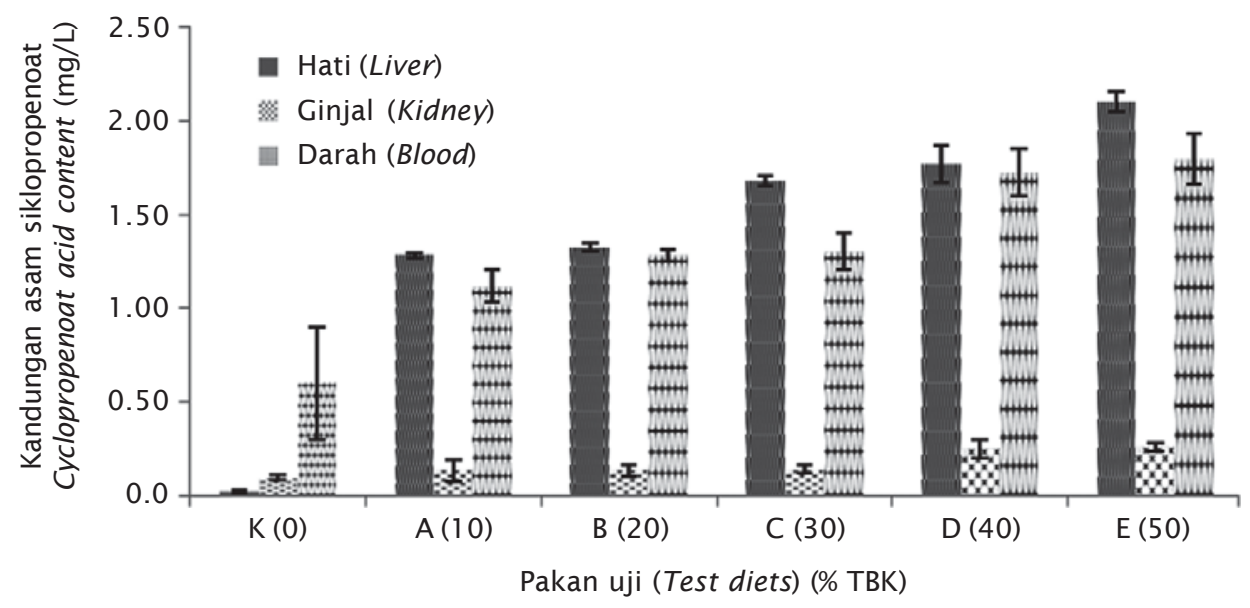

Gambar 4. Kandungan asam siklopropenoat dalam jaringan tubuh ikan mas setelah pemberian pakan uji

Figure 4. Cyclopropenoat acid content in some tissue of fish test after feeding period

Hasil pengukuran kandungan haemoglobin (Gambar 5A) dan hematokrit (Gambar 5B) menunjukkan adanya kecenderungan menurun dengan meningkatnya jumlah penggunaan tepung biji kapuk dalam pakan. Kadar haemoglobin dan haemotokrit ikan mas yang normal berturut-turut berkisar 6,40-7,01\% dan 27,129,62\% (Moyle \& Cech, 2004). Rendahnya kadar haemoglobin dan haemotokrit darah ikan pada penelitian ini diduga telah terjadi gejala kondisi anemia (Post, 1987). Menurut Lee et al. (2002), gejala anemia pada ikan yang diberi pakan mengandung gossypol disebabkan karena pengaruh akumulasi gossypol dan rendahnya ketersediaan zat besi dari bahan yang mengandung gossypol tersebut.

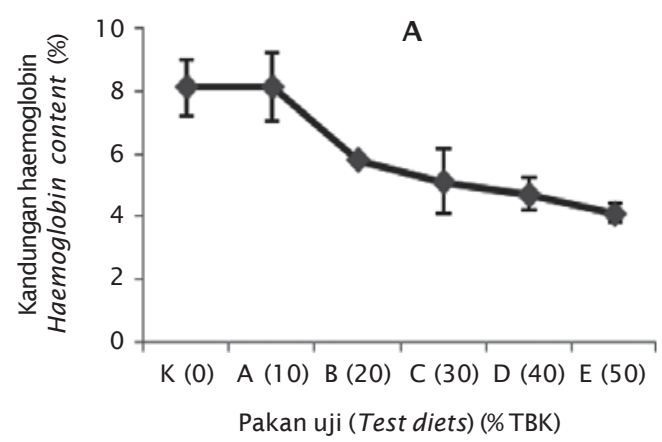

Penggunaan tepung biji kapuk dalam pakan ikan belum banyak dilaporkan, namun penggunaan $30 \%$ TBK dalam pakan yang diberikan pada yuwana udang vaname menunjukkan tingkat sintasan yang semakin menurun dan mortalitas mencapai 100\% pada hari keenam (Utami, 2008). Muskita (2012) menyatakan bahwa asam lemak siklopropenoat dan gossypol yang terkandung dalam pakan yang mengandung $810 \%$ TBK telah mengakibatkan kerusakan hepatopankreas, penurunan aktivitas enzim pencernaan, perubahan komposisi asam lemak tubuh, menurunkan jumlah konsumsi pakan serta penurunan sintasan yuwana udang vaname.

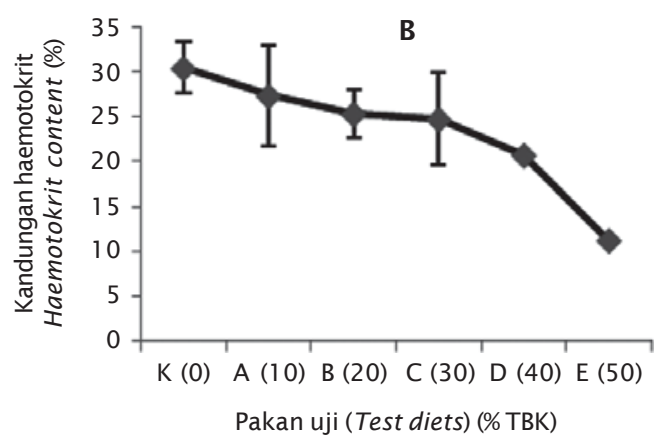

Gambar 5. Total kandungan haemoglobin (A) dan total haemotokrit (B) dalam darah ikan uji yang diberi pakan bertepung biji kapuk berbeda

Figure 5. Total haemoglobin content ( $A$ ) and total haemotokrit (B) count in blood test fish after feeding period 
Setelah pemeliharaan ikan selama 60 hari, kinerja pertumbuhan ikan dan pemanfaatan pakan uji disajikan pada Gambar 6. Pada Gambar 6 tersebut terlihat bahwa kinerja pertumbuhan ikan seperti bobot akhir, laju pertumbuhan harian, dan sintasan ikan terdapat berbedaan yang nyata $(P<0,05)$ di antara perlakuan. Semakin tinggi kandungan tepung biji kapuk dalam pakan, kinerja pertumbuhan ikan tersebut semakin menurun. Penggunaan tepung biji kapuk sebanyak $10 \%$ dalam pakan uji tersebut sudah menurunkan secara nyata $(P<0,05)$ pertumbuhan ikan mas dibandingkan ikan yang diberi pakan tanpa tepung biji kapuk. Bahkan pada penggunaan $50 \%$ tepung biji kapuk dalam pakan, ikan sudah mengalami pertumbuhan negatif, meskipun ikan mengonsumsi pakan. Hal ini menunjukkan bahwa pada kandungan $10 \%$ tepung biji kapuk dalam pakan, ikan mas sudah tidak dapat memanfaatkan
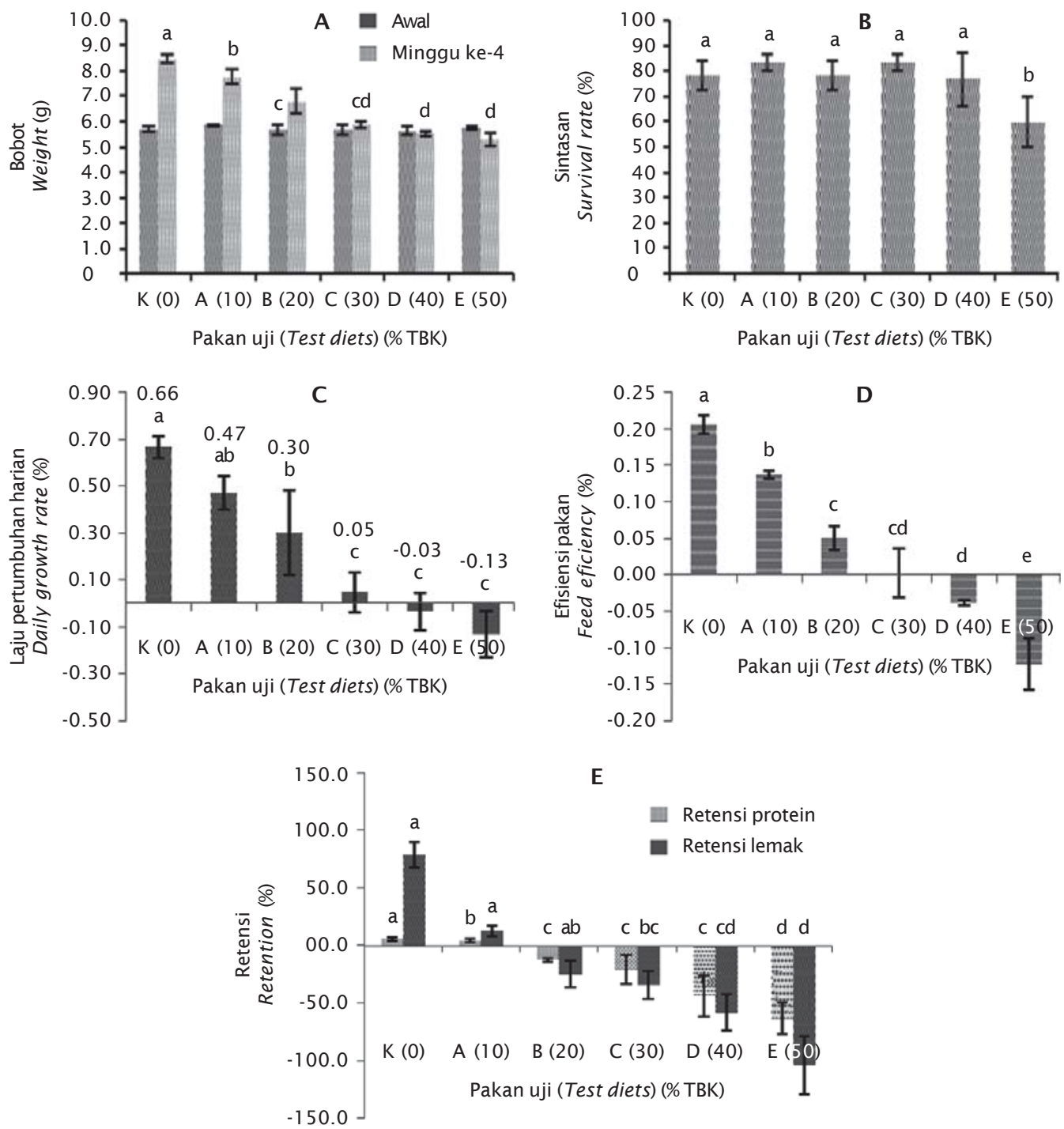

Gambar6. Kinerja pertumbuhan dan pemanfaatan pakan ikan mas yang diberi pakan uji mengandung tepung biji kapuk berbeda

Figure 6. Growth performance and feed utilization of common carp fed diets containing different levels of kapook seed meal 
pakan tersebut dengan baik untuk pertumbuhannya.

Tingkat pemanfaatan pakan uji seperti efisiensi pakan, retensi protein, dan retensi lemak terdapat perbedaan yang nyata $(P<0,05)$ di antara perlakuan. Semakin tinggi penggunaan tepung biji kapuk dalam pakan, menyebabkan tingkat pemanfaatan pakan semakin rendah. Penggunaan tepung biji kapuk sebanyak $10 \%$ dalam pakan sudah menurunkan secara nyata $(P<0,05)$ efisiensi pakan dan retensi lemak dibandingkan ikan yang diberi pakan tanpa kandungan tepung biji kapuk. Sementara retensi protein masih relatif sama $(P>0,05)$ pada ikan yang diberi pakan dengan kandungan tepung biji kapuk 10\% dengan yang diberi pakan tanpa tepung biji kapuk, namun retensi proteinnya mulai menjadi negatif ketika kandungan tepung biji kapuk meningkat menjadi $20 \%$ dalam pakan.

\section{KESIMPULAN}

Berdasarkan kecernaan pakan, gambaran darah, akumulasi zat anti nutrisi dalam organ, dan kinerja pertumbuhan, biji kapuk tidak dapat digunakan sebagai bahan baku pakan ikan mas pada kadar $810 \%$ dalam pakan. Penggunaan tepung biji kapuk sebanyak $<10 \%$ dalam pakan ikan mas masih perlu dikaji.

\section{DAFTAR ACUAN}

Abimorad, E.G. \& Carneiro, D.J. 2007. Digestibility and performance of pacu (Piaractus mesopotamicus) juveniles fed diets containing different protein, lipid and carbohydrate levels. Aquaculture Nutrition, 13: 1-9.

Allan, G.L., Parkinson, S., Booth, M.A., Stone, D.A.J., Rowland, S.J., Frances, J., \& WarnerSmith, R. 2000. Replacement of fish meal in diets for Australian silver perch Bidyanus bidyanus, Digestibility of alternative ingredients. Aquaculture, 186: 293-310.

Association of Official Analytical Chemists (AOAC). 1995. Official methods of analysis. 16th edn. AOAC, Arlington, 1,094 pp.

Ayuningsih, B. 1994. Pengaruh penggunaan bungkil biji kapuk (Ceiba petandra) terhadap produksi dan komposisi susu kambing perah. Tesis, Program Pascasarjana Institut Pertanian Bogor.

Bergmeyer, H.U. \& Grassi M. 1983. Methods of Enzimatic Analysis. Vol. V : Enzymes 3 : Peptidases, proteinases and their inhibi- tors. VCH Verlagsgesellschafc $\mathrm{MBH}$, Weinheim, $582 \mathrm{pp}$.

Bores, G.E., Cerecedo, R.C., Meza, S.R., \& Yee, A.G. 2006. Partial replacement of red crab (Pleuroncodes planics) meal for fish meal in vivo digestibility. Aquaculture, 256: 414422.

Borlongan, T.G. 1990. Studies on lipases of milkfish (Chanos chanos). Aquaculture, 89: 315-325.

Cai, Y., Zhang, H., Zeng, Y., Mo, J., Bao, I., Miao, C., Bai, I., Yann, F., \& Chen, F. 2004. An optimazed gossypol high-performance liquid chromatography assay and Its application in evaluatio haln of different gland genotypes of cotton. Journal Bio Sci, 29: 67-71.

Chamkasem, N. 1988. Gossypol analysis in cottonseed oil by HPLC. Journal of the American Oil Chemists' Society, 65:1,6011,604 .

Francis, G., Hannder, P.S.M., \& Becker, K. 2001. Antinutritional factors present in plantderived alternate fish feed ingredients and their effects in fish. Aquaculture, 199: 197227.

Hartutik. 2000. Evaluasi nilai nutrisi bungkil biji kapuk randu, Ceiba petandra Gaertn, dalam ransum ruminansi. Disertasi, Pascasarjana UGM. Jogyakarta, $464 \mathrm{hlm}$.

Hertrampf, I.W. \& Felicitas, P. 2000. Handbook on Ingredients for Aquaculture Feeds. Kluwer Academic Publishers. Dorcirechtl Boston/London, $573 \mathrm{pp}$.

Humason, G.L. 1985. Animal Tissue Technique. Fourth Edition. WN Freeman and Company, San Fransisco, USA, 600 pp.

Huisman, E.A. 1976. Food convertion efficiencies at maintenance and production level for carp, Cyprinus carpio $L$ and rainbow trout, Salmon gairdneri R. Aquaculture, 9: 259-273.

Lee, K.J, Dabrowski, K., Blom, J.H., Bai, S.C., \& Stromberg, P.C. 2002. A mixture of cotton seed meal, soybean meal and animal by product mixture as a fish meal substitute: growth and tissue gossypol enantiomer in juvenile rainbow trout (Oncorhynchus mykiss). Journal of Animal Physiology and Animal Nutrition, 86: 201-213.

Li, M.H. \& Robinson, E.H. 2006. Use of cottonseed meal in aquatic animal diets: a review. North American Journal of Aquaculture, 68: 14-22. 
Luo, L., Xue, M., Wu, X., Cai, X., Cao, H., \& Liang, Y. 2006. Partial or total replacement of fishmeal by solvent-extracted cottonseed meal in diets for juvenile rainbow trout (Oncorhynchus mykiss). Aquaculture Nutrition, 12: 418-424.

Mairizal. 1998. Siklus birahi dan profil hormon progesteron serta estradiol kambing peranakan etawah yang diberi pakan mengandung bungkil biji kapuk. Tesis. Program Pascasarjana, Institut Pertanian Bogor. Bogor, $40 \mathrm{hlm}$.

Mazida, A.N. 2007. Penggunaan protein nabati dengan dan tanpa penambahan enzimfitase sebagai bahan baku pakan lele dumbo (Clarias sp.). Tesis. Sekolah Pascasarjana, Institut Pertanian Bogor. Bogor, $55 \mathrm{hlm}$.

Mbahinzireki, G.B., Dabrowski, K., Lee, K.J., ElSaidy, D., \& Wisner, E.R. 2001. Growth, feed utilization, and body composition of tilapia (Oreochromis spp.) fed with cottonseed meal-based diets in a recirculating system. Aquaculture Nutrition, 7: 189-200.

Morgan, S.E. 1989. Gossypol as a toxicant in livestock. In: Burrows, G.E (ed.). The Veterinary Clinics of North America: Food Animal Practice. Philadelphia, p. 251-263.

Moyle, P.B. \& Cech, Jr.J. 2004. Fishes. An Introduction to Ichthyology. $5^{\text {th }}$ ed. USA. Prentice Hall, Inc. 744 pp.

Muskita, W.H. 2012. Substitusi tepung bungkil kedele, Glycine max, dengan tepung bungkil biji kapuk, Ceiba petandra, dalam pakan juvenil udang vaname Litopenaeus vannamei: Kajian histologi, enzimatik, dan komposisi asam lemak tubuh. Disertasi. Sekolah Pascasarjana Institut Pertanian Bogor. Bogor, $120 \mathrm{hlm}$.

National Research Council (NRC). 1993. Nutrient Requirement of Fish. National Academy Press, Washington. D.C., 114 pp.

Parakkasi, A. 1983. Ilmu Gizi dan Makanan Ternak Monogastrik. Angkasa, Bandung, $514 \mathrm{hlm}$.

Phelps, R.A., Shenstone, F.S., Kemmerer, A.R., \& Evans, R.J. 1964. A Review of cyclopropenoid compounds: biological effect of some derivatives. Poultry Sci., 44: 358-394.
Post, G. 1987. Texbook of Fish Health. T.F.H. Publications, Neptune City, Nj, USA.

Robinson, E.H. \& Brent, J.R. 1989. Use of cottonseed meal protein with supplemental lysine in feeds for channel catfish. J. Appl. Aquaculture, 1(2): 1-14.

Robinson, E.H. \& Li, M.H. 1994. Use of plant proteins in catfish feeds: replacement of soybean meal with cottonseed meal and replacement of fish meal with soybean meal and cottonseed meal. J. World Aquacult. Soc., 25: 271-276.

Sangadji, I. 1998. Aspek nutrisi dan pubertas kambing dara yang diberi konsentrat dengan penambahan bungkil biji kapuk (Ceiba petandra). Tesis. Program Pasca sarjana Institut Pertanian Bogor. Bogor, 65 hlm.

Takeuchi, T. 1988. Laboratory work-chemical evaluation of dietary nutrients. In: Watanabe, T. (ed). Fish Nutrition and Mariculture. Tokyo: Departemen of Aquatic Bioscience, University of Fisheries, p. 179233.

Utami, D.S.N. 2008. Kecernaan dan pertumbuhan juvenil udang putih Litopenaeus vannamei yang diberi pakan dengan pemakaian bungkil kelapa sawit, lupin, biji kapuk dan bungkil kedelai masing-masing 30\%. Skripsi. Fakultas Perikanan dan IImu Kelautan, Institut Pertanian Bogor. Bogor, $40 \mathrm{hlm}$.

Wilson, R.P. 2002. Amino acids and proteins. In: Halver, J.E., Hardy, R.W. (eds.). Fish Nutrition. New York: Academic Press, p. 143-1 79.

Yildirim, M., Lim, C., Wan, P., \& Klesius, P.H. 2004. Effect of natural free gossypol and gossypol-acetic acid on growth performance and resistance of channel catfish (Ictalurus puncatutus) to Edwardsiella ictalurichaleng. Aquaculture Nutrition, 10: 153-165.

Zahirma, U. 1986. Analisa asam siklopropenoat dari bungkil biji kapuk dengan teknik kromatografi gas. Skripsi. FMIPA, Universitas Indonesia. Jakarta, $43 \mathrm{hlm}$.

Zonneveld, N., Huisman, E.A., \& Boon, J.H. 1991. Prinsip-prinsip Budidaya Ikan. PT. Gramedia Pustaka Utama, Jakarta, $318 \mathrm{hlm}$. 